\title{
REVIEW \\ Neuroplasticity of ascending and descending pathways after somatosensory system injury: reviewing knowledge to identify neuropathic pain therapeutic targets
}

\author{
P Boadas-Vaello ${ }^{1}$, S Castany ${ }^{1}$, J Homs ${ }^{1,2}$, B Álvarez-Pérez ${ }^{1}$, M Deulofeu $^{1}$ and E Verdú ${ }^{1}$
}

\begin{abstract}
Study design: This is a narrative review of the literature.
Objectives: This review aims to be useful in identifying therapeutic targets. It focuses on the molecular and biochemical neuroplasticity changes that occur in the somatosensory system, including ascending and descending pathways, during the development of neuropathic pain. Furthermore, it highlights the latest experimental strategies, based on the changes reported in the damaged nociceptive neurons during neuropathic pain states.

Setting: This study was conducted in Girona, Catalonia, Spain.

Methods: A MEDLINE search was performed using the following terms: descending pain pathways; ascending pain pathways; central sensitization; molecular pain; and neuropathic pain pharmacological treatment.

Results and conclusion: Neuropathic pain triggered by traumatic lesions leads to sensitization and hyperexcitability of nociceptors and projection neurons of the dorsal horn, a strengthening in the descendent excitatory pathway and an inhibition of the descending inhibitory pathway of pain. These functional events are associated with molecular plastic changes such as overexpression of voltagegated ion channels, algogen-sensitive receptors and synthesis of several neurotransmitters. Molecular studies on the plastic changes in the nociceptive somatosensory system enable the development of new pharmacological treatments against neuropathic pain, with higher specificity and effectiveness than classical drug treatments. Although research efforts have already focused on these aspects, additional research may be necessary to further explore the potential therapeutic targets in neuropathic pain involved in the neuroplasticity changes of neuropathological pathways from the injured somatosensory system.
\end{abstract}

Spinal Cord (2016) 54, 330-340; doi:10.1038/sc.2015.225; published online 12 January 2016

\section{INTRODUCTION}

The International Association for the Study of Pain describes the term of neuropathic pain as 'the pain initiated or caused by a primary lesion or dysfunction in the nervous system.' ${ }^{1}$ However, the Special Interest Group 'Neuropathic Pain' from the International Association for the Study of Pain has proposed a new definition, in which neuropathic pain is stated as 'the pain initiated or caused by a lesion or disease of the somatosensory system'. ${ }^{2}$ This new definition replaces the word 'dysfunction' for 'disease' in order to underline the difference between neuropathic pain and the pain caused by the plastic changes that occur in response to an intense nociceptive stimulation. Similarly, the replacement of the 'nervous system' concept by the term 'somatosensory system' has emerged as a need to differentiate neuropathic pain from the pain caused by an eventual lesion in other specific areas of the nervous system (for example, pain associated with the muscle spasticity caused by injuries in the motor tract). In summary, the new proposed definition postulates that lesions and/or diseases of the peripheral and central somatosensory system cause neuropathic pain. ${ }^{2,3}$ The results of this system can be because of traumatic lesions, inflammation, infections, cancer infiltrations, as well as because of consequences derived from pharmacological treatments (for example, chemotherapy and anti-retroviral therapy). ${ }^{4-7}$

Traumatic lesions of the somatosensory system lead to the onset of neuropathic pain, characterized by spontaneous pain, allodynia and hyperalgesia. ${ }^{8}$ Traffic collisions are the main cause of nerve injury, affecting over 3.2 million people worldwide. Pain is involved in $65 \%$ of people with traumatic neuropathies, and $50 \%$ of them are diagnosed with neuropathic pain. Most of these traumatic peripheral neuropathies affect young men (20-40 years old), and the damage is mainly located in the upper limb nerves. ${ }^{9}$ Traffic accidents are also the leading cause of spinal cord lesion in young people, among which two-thirds of patients develop neuropathic pain. ${ }^{10-13}$ In the United States, the annual socioeconomic cost of neuropathic pain derived from traumatic injuries in the somatosensory system is $\sim 100$ billion US dollars. $^{14}$

Some experimental studies have shown that the physiopathological mechanisms of neuropathic pain are associated with nociceptor sensitization, spontaneous and ectopic firing of afferent nociceptive fibers and with changes in the molecular expression of ion channels, neurotransmitters and receptors in the nociceptive axons, as well as in

${ }^{1}$ Research Group of Clinical Anatomy, Embryology and Neuroscience (NEOMA), Department of Medical Sciences, Universitat de Girona, Girona, Spain and ${ }^{2}$ Department of Physical Therapy, EUSES - Universitat de Girona, Girona, Spain

Correspondence: Dr P Boadas-Vaello, Research Group of Clinical Anatomy, Embryology and Neuroscience (NEOMA), Department of Medical Sciences, Facultat de Medicina, Universitat de Girona, Carrer Emili Grahit 77, 2a planta, Girona E-17071, Spain.

E-mail: pere.boadas@udg.edu

Received 30 April 2015; revised 25 November 2015; accepted 28 November 2015; published online 12 January 2016 
a

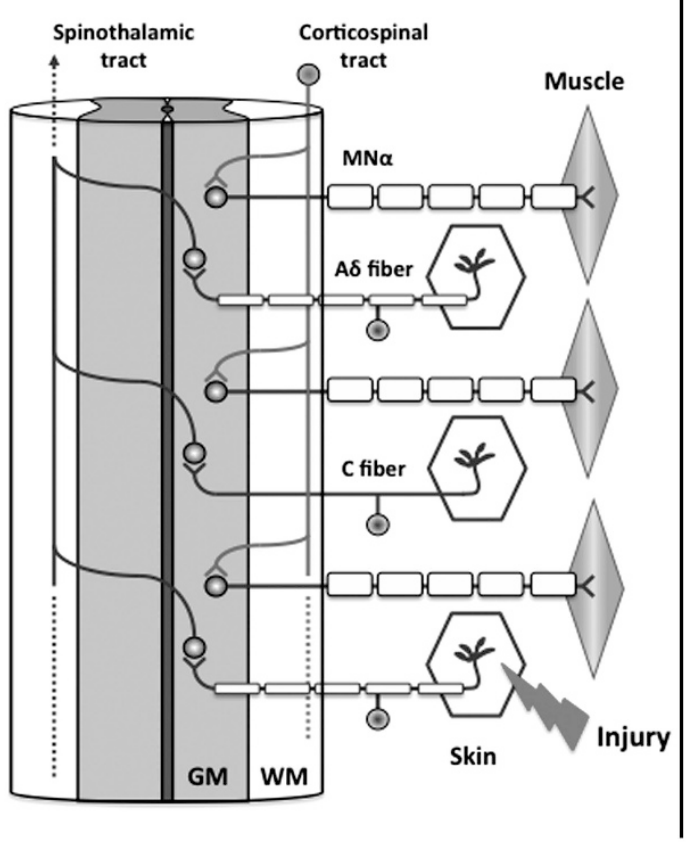

b



Figure 1 Schematic representation of nociceptive ascending somatosensory pathways. (a) Afferent $A \delta$ and $C$ nerve fibers from skin project to the nociceptive neurons located in the gray matter (GM) of the dorsal horn of spinal cord. Part of projection neurons of dorsal horn constitutes the spinothalamic tract that transmits pain up to thalamic neurons. Other nociceptive ascending pathways are not represented. Injury of the skin or other tissues causes the activation of afferent nociceptive fibers. (b) Tissue injury causes the generation of several algogenic mediators that bind to ion channels or metabotropic receptors of nociceptors, and improve an influx of calcium ions and the generation of second-messengers [1]. Both intracellular mediators are able to facilitate the transcription of target genes [2] and the translation of new proteins such as voltage-gated ion channels [3] that contribute to the hyperexcitability of afferent nociceptive nerve fibers [4]. Excited afferent nociceptive neurons release more neurotransmitters over spinal cord neurons [5], inducing not only the excitation of these nociceptive neurons but also contributing to the sensitization of central neurons [6], and the hyperexcitability of these neurons from the spinothalamic tract.

the dorsal root ganglia neurons. At the spinal cord level, sensitization of second-order nociceptive neurons (central sensitization) and changes in the neurotransmitters, neuropeptides and receptor expression are the main changes established within the framework of neuropathic pain. Moreover, additional changes may involve the dysregulation of the inhibitory interneurons in the dorsal horn and the descending modulatory pathways, glial cell reactivation following the synthesis and release of proinflammatory cytokines and, finally, a morphological and functional reorganization of the afferent projections in the dorsal horn. ${ }^{15-18}$

Despite the fact that neuropathic pain physiopathology has been thoroughly studied, a detailed study focusing on the plastic processes affecting nociceptive neurons in an injured somatosensorial system could involve a double implication: (1) a novel approach in the identification of either molecular or cellular targets involved in neuropathic pain; and (2) it could also shed some light in the design of new therapeutic strategies for neuropathic pain states. Therefore, the aim of the present review is to look over the molecular and biochemical neuroplasticity changes that occur in the somatosensory system during the development of neuropathic pain.

\section{MOLECULAR NEUROPLASTICITY OF ASCENDING PAIN PATHWAY IN INJURED SOMATOSENSORY SYSTEM: SPINAL AND SUPRA-SPINAL CENTERS}

The nociceptive somatosensory pathway is initially composed of nociceptors or nociceptive neurons of first order, which are free nerve endings (type $\mathrm{A} \delta$ and $\mathrm{C}$ sensory fibers) that transduce noxious stimulus from damaged peripheral tissues to the spinal cord and/or the brainstem. Primary afferent nociceptive neurons (type $A \delta$ and $\mathrm{C}$ fibers) synapse with second-order neurons (specific nociceptive neurons and wide-dynamic range neurons) and inhibitory/excitatory interneurons located in the first layers of the dorsal horn. The axons of these spinal neurons are considered to form the spinothalamic tract, ending as synapses to thalamic neurons that in turn eventually send projections to different brain cortical areas. It is important to note that the spinothalamic tract, in its upward pathway, also generates collateral projections to neuronal groups located in the brainstem. ${ }^{19}$ Primary nociceptive neurons release glutamate, substance P (SP), calcitonin gene-related peptide and adenosine triphosphate (ATP) that act as neurotransmitters and neuromodulators, distributed either in axon terminal projections from the dorsal horn of the spinal cord or in peripheral endings of primary sensory $\mathrm{A} \delta / \mathrm{C}$ nerve fibers (Figure 1). Similarly, these neurons have a wide variety of ionic channels and membrane receptors on which several algogen molecules interact ${ }^{20,21}$ (Table 1).

Several experimental studies have shown that lesions in peripheral nerves and inflammation of skin, muscle joints and internal organs cause phenotypic changes in sensory afferent fibers, induced by an excessive calcium influx in these afferent fibers or by the interaction of inflammatory mediators with their respective receptors located in the cell membrane of these afferent fibers. All these extracellular signals induce gene expression changes in sensory nociceptive afferent neurons, resulting in voltage-gated ion channels, ligands and metabotropic receptor overexpression ${ }^{22,23}$ (Table 2).

Some functional consequences stemming from the aforementioned phenotypic changes include increased sensitization and depolarization 
of nociceptors to different algogens by overexpression of acid-sensing ion channels (ASIC), hyperpolarization-activated cyclic nucleotidegated channels and transient receptor potential ion channels (TRP), whereas increased action potential generation and its extensive

Table 1 Main algogens that interact with nociceptive neurons of somatosensory system

\begin{tabular}{|c|c|c|}
\hline Algogen & Receptor & Action \\
\hline \multicolumn{3}{|c|}{$\begin{array}{l}\text { (A) Algogenic substances that stimulate tissue nociceptors or first-order nociceptive } \\
\text { neurons after injury and/or tissue inflammation }\end{array}$} \\
\hline Acetylcholine & Muscarinic and nicotinic & Activation after injury \\
\hline ATP & $\mathrm{P} 2 \mathrm{X}$ & Activation \\
\hline Bradykinin & $\mathrm{B} 1$ and $\mathrm{B} 2$ & Activation \\
\hline Capsaicin & TRPV1 & Activation \\
\hline Catecholamines & $\alpha$-Adrenergic & Activation after injury \\
\hline CGRP & CGRP-R & Activation/sensitization \\
\hline $\mathrm{H}^{+}$ & ASIC channels & Activation/sensitization \\
\hline Histamine & $\mathrm{H} 1$ receptors & Activation/sensitization \\
\hline Nitric oxide & Diffusion & Sensitization \\
\hline Prostaglandins & Prostaglandin receptor & Activation/sensitization \\
\hline Serotonin & 5-HT1A, 5-HT3 & Activation/sensitization \\
\hline Substance P & NK1 & Activation/sensitization \\
\hline \multicolumn{3}{|c|}{$\begin{array}{l}\text { (B) Algogenic substances in the spinal cord parenchyma that stimulate nociceptive } \\
\text { neurons of the second order (spinothalamic tract) following nerve injury and/or spinal } \\
\text { cord }\end{array}$} \\
\hline ATP & P2X & Activation/sensitization \\
\hline CCL2 o MCP1 & CCR2 & Activation/sensitization \\
\hline CGRP & CGRP-R & Activation/sensitization \\
\hline IL-1 and IL-6 & Interleukin receptor & Activation/sensitization \\
\hline Nitric oxide & Diffusion & Sensitization \\
\hline Substance $P$ & NK1 & Activation/sensitization \\
\hline TNF- $\alpha$ & TNF-R & Activation/sensitization \\
\hline
\end{tabular}

Abbreviations: ASIC, acid-sensing ion channels; ATP, adenosine triphosphate; CGRP, calcitonin gene-related peptide; IL, interleukin; TNF, tumor necrosis factor.

Source: Gao and $\mathrm{Ji}^{51}$ and Xifró et al. ${ }^{18}$. propagation through nociceptive fibers by overexpression of voltagegated sodium channels might also be another functional consequence. Nociceptor hyperexcitability results in a greater release of neurotransmitters (glutamate, SP, calcitonin gene-related peptide, ATP) to second-order nociceptive neurons in the spinal cord (Figure 1; Table 2), including projection neurons nociceptive specific neurons called NS neurons and wide dynamic range neurons called WDR neurons and interneurons (excitatory and inhibitory). All the physiological processes taking place within injured nociceptive fibers also contribute to the reduction of $\mathrm{K}_{\mathrm{ATP}}$ channels. At physiological levels of intracellular ATP concentration, $\mathrm{K}_{\mathrm{ATP}}$ channels are inhibited, whereas activation is stated whenever a decrease of intracellular ATP occurs as a consequence of energy depletion in the injured neuron. Activation subsequently causes an outflow of potassium ions that leads to neuronal hyperpolarization, as well as to a decrease in the neuronal excitability and to a reduction in the release of neurotransmitters. The decrease in $\mathrm{K}_{\mathrm{ATP}}$ expression, after a peripheral nerve axotomy in myelinated nociceptive fibers (A $\delta$ type), enhances the hyperexcitability of the damaged nociceptive fibers. ${ }^{24,25}$ Sensitization and hyperexcitability of injured peripheral nociceptors also induce hyperexcitability of nociceptive spinal neurons, triggering within an increase of electric activity, the expansion of their receptor field and a threshold decrease to afferent inputs as a result of overexpression of ionic channels and receptors. The explained plastic changes in spinal nociceptive neurons are known as 'central sensitization'. 26,27

The aforementioned neurotransmitters interact with N-methylD-aspartate receptor (NMDA), $\alpha$-amino-3-hydroxy-5-methyl-4isoxazolepropionic acid receptor (AMPA), metabotropic receptors of glutamate (mGluR), neurokinin-1 receptor (NK1R) and purinergic receptors $(\mathrm{P} 2 \mathrm{X})$ of spinal nociceptive projection neurons ${ }^{28-35}$ causing their depolarization and the generation of painful signals to be scattered throughout the nociceptive spinothalamic pathway. In turn, this chemical neurotransmission causes an influx of calcium ions in the spinal nociceptive neurons of second order, ${ }^{36}$ a process that activates calcium-dependent intracellular cascades, inducing phosphorylation sensitization ${ }^{37}$ and ionic channel and membrane receptor overexpression (Table 3). Moreover, the neurotransmitters and

Table 2 Main molecular changes of nociceptors after injury and/or tissue inflammation

\begin{tabular}{|c|c|c|c|}
\hline $\begin{array}{l}\text { Type of channel and/or } \\
\text { receptor }\end{array}$ & Class of receptor or ion channel & Result of the change & Reference (s) \\
\hline \multirow[t]{2}{*}{$\begin{array}{l}\text { Voltage-gated ion channels } \\
\text { (increase of their expression) }\end{array}$} & $\begin{array}{l}\text { Sodium ions: Nav1.3, Nav1.7, } \\
\text { Nav1.8 and Nav1.9 }\end{array}$ & $\begin{array}{l}\text { Hyperexcitability of fibers A } \delta \text { and } C \text {. Increase of nerve } \\
\text { conduction of these nerve fibers. Generation of } \\
\text { ectopic discharges. }\end{array}$ & $\begin{array}{l}\text { Zimmermann, }{ }^{15} \text { Lai et al., } 119 \\
\text { Cummins et al., }{ }^{120} \text { Wood et al., }{ }^{121} \\
\text { Lampert et al. }^{122} \text { and Berger et al.. }\end{array}$ \\
\hline & Calcium ions: $\mathrm{N}, \mathrm{P} / \mathrm{Q}$ & $\begin{array}{l}\text { Increase of neurotransmitter release on nociceptive } \\
\text { spinal cord neurons. Sensitization of nociceptors. }\end{array}$ & $\mathrm{Cao}^{124}$ \\
\hline \multirow[t]{4}{*}{$\begin{array}{l}\text { Ligand-gated ion channels } \\
\text { (increase of their expression) }\end{array}$} & Gated by nucleosides: HCN & $\begin{array}{l}\text { Easy to depolarize by inflammatory stimuli } \\
\text { (prostaglandins, nitric oxide). Increased release of NTs } \\
\text { on spinal neurons. }\end{array}$ & Jiang et al. ${ }^{125}$ and Emery et al. ${ }^{126}$ \\
\hline & Sensitive to acidosis: ASIC & $\begin{array}{l}\text { Easily depolarized by hydrogenions. Increased release } \\
\text { of NTs on spinal neurons. }\end{array}$ & Bianchi and Driscoll ${ }^{127}$ and Lingueglia ${ }^{128}$ \\
\hline & Purinergic receptors: P2X & Neurotransmission spinal favors. & $\begin{array}{l}\text { Chizh and Illes, }{ }^{28} \text { Ding et al. }{ }^{129} \text { and } \\
\text { Tsuda et al. }{ }^{130}\end{array}$ \\
\hline & $\begin{array}{l}\text { TRP receptors: vanilloid (TRPV1, } \\
\text { TRPV2), melastatin (TRPM8) and } \\
\text { ankyrin (TRPA1) }\end{array}$ & $\begin{array}{l}\text { Easy to depolarize by inflammatory stimuli. Increased } \\
\text { release of NTs on spinal neurons. }\end{array}$ & Jara-Oseguera et al. ${ }^{131}$ and Stucky et al. ${ }^{132}$ \\
\hline $\begin{array}{l}\text { Ligand-gated ion channels } \\
\text { (decrease of their expression) }\end{array}$ & $\begin{array}{l}\text { Sensitive potassium channels } \\
\text { to ATP: } K_{\text {ATP }}\end{array}$ & Enhancing the hyperexcitability of nociceptive fibers. & Zoga et al. ${ }^{24}$ and Sarantopoulos et al. ${ }^{25}$ \\
\hline
\end{tabular}

Abbreviations: ASIC, acid-sensing ion channels; ATP, adenosine triphosphate; HCN, hyperpolarization-activated cyclic nucleotide-gated channels; NTs: neurotransmitters; TRP, transient receptor potential ion channels. 
Table 3 Main molecular changes of spinothalamic neurons and thalamic neurons that process pain responses

\begin{tabular}{|c|c|c|c|}
\hline Neuron & Class of receptor or ion channel & Result of the change & Reference (s) \\
\hline \multirow[t]{6}{*}{$\begin{array}{l}\text { Spinal neuron second order } \\
\text { (spinothalamic pathway) }\end{array}$} & $\begin{array}{l}\text { Sodium voltage-gated ion channels (increase } \\
\text { of their expression): Nav1.3 }\end{array}$ & $\begin{array}{l}\text { Hyperexcitability of spinal nociceptive neurons. } \\
\text { Increased nerve conduction in these neurons. }\end{array}$ & $\begin{array}{l}\text { Hains et al. }{ }^{133} \text { and Spicarova } \\
\text { et al. }{ }^{134}\end{array}$ \\
\hline & $\begin{array}{l}\text { Calcium voltage-gated ion channels (increase } \\
\text { of their expression): } N, P / Q\end{array}$ & $\begin{array}{l}\text { Increased release of thalamic neurons NTs; Sensi- } \\
\text { tization of spinal nociceptive neurons. }\end{array}$ & Li et al. ${ }^{135}$ and Boroujerdi et al. ${ }^{136}$ \\
\hline & $\begin{array}{l}\text { Ligand-gated ion channels: large conductance } \\
\mathrm{Ca}^{2+} \text {-activated } \mathrm{K}^{+} \text {channel } \mathrm{BK}_{\mathrm{Ca}}\end{array}$ & & Chen et al. ${ }^{137}$ \\
\hline & $\begin{array}{l}\text { Ligand-gated ion channels (increase of their } \\
\text { expression): TRPV1, ASIC and glutamatergic } \\
\text { receptors }\end{array}$ & $\begin{array}{l}\text { Easily depolarized by hydrogenions, inflammatory } \\
\text { mediators and glutamate released during spinal } \\
\text { cord injury }\end{array}$ & $\begin{array}{l}\text { Luo et al., }{ }^{138} \text { Wu et al. }{ }^{139} \text { and } \\
\text { Galan et al. }{ }^{140}\end{array}$ \\
\hline & $\begin{array}{l}\text { Decreased expression of the KCC2 } \\
\text { cotransporter }\end{array}$ & $\begin{array}{l}\text { Disinhibition of spinal action of GABA neurons } \\
\text { mediated by GABA-A receptor }\end{array}$ & $\begin{array}{l}\text { Coull et al., }{ }^{141} \text { Lu et al. }{ }^{142} \text { and } \\
\text { Price et al. }{ }^{143}\end{array}$ \\
\hline & Decreased expression of GABAergic receptors & $\begin{array}{l}\text { No inhibition of spinal neurons by the action of } \\
\text { GABA }\end{array}$ & Castro-Lopes et al. ${ }^{144}$ \\
\hline \multirow[t]{2}{*}{ Pain thalamic neuron } & $\begin{array}{l}\text { Voltage-gated ion channels (increase of their } \\
\text { expression) for sodium (Nav1.3) and calcium } \\
(\mathrm{N}, \mathrm{P} / \mathrm{Q} \text { ) ions }\end{array}$ & $\begin{array}{l}\text { Hyperexcitability of thalamic neurons and increased } \\
\text { NTs on cortical neurons. Sensitization of thalamic } \\
\text { neurons }\end{array}$ & $\begin{array}{l}\text { Hains et al.., }{ }^{145} \text { Zhao et al., }{ }^{146} \\
\text { Todorovic and Jevtovic-Todorovic }{ }^{147}\end{array}$ \\
\hline & Decreased expression of GABAergic receptors & $\begin{array}{l}\text { No inhibition of thalamic neurons by the action of } \\
\text { GABA }\end{array}$ & $\begin{array}{l}\text { Ralston et al., }{ }^{148} \text { Jeanmonod } \\
\text { et al. }{ }^{149} \text { and Weng et al. } 150\end{array}$ \\
\hline
\end{tabular}

Abbreviations: ASIC, acid-sensing ion channels; ATP, adenosine triphosphate; GABA, $\gamma$-aminobutyric acid; HCN, hyperpolarization-activated cyclic nucleotide-gated channels; NTs: neurotransmitters; TRP, transient receptor potential ion channels.

neuromodulators released from nociceptive primary afferent fibers in the dorsal horn interact with glutamate receptors (NMDA, AMPA), $\mathrm{SP}$ receptor (NK1), purinergic receptors $(\mathrm{P} 2 \mathrm{X}, \mathrm{P} 2 \mathrm{Y})$ and calcitonin gene-related peptide receptors of microglia and astrocytes. ${ }^{38-42}$ Reactive microglial cells synthesize and release cytokines (IL1, IL6, TNF-alpha), prostaglandins (PGE2), chemokines (MCP-1 or CCL2) and nitric oxide, which act as chemical mediators that amplify the microglial reactivity in a paracrine manner, favoring the elevation of these mediators in the dorsal horn of the spinal cord. ${ }^{43}$ Reactive microglial cells are also responsible for the release of cathepsine-S protease that causes the proteolysis of a trans-membrane glycoprotein called fractalkine (CX3CL1). This protein is located in the plasma membrane of terminal axons in afferent nociceptive fibers (A $\delta$ and $\mathrm{C}$ ) that project to the dorsal horn, as well as in spinal projection nociceptive neurons. This proteolysis releases the active fragment of fractalkine, which interacts with the fractalkine receptor (CX3XR1) located in the reactive microglial cell membrane, maintaining its reactivity ${ }^{44-46}$ and therefore contributing to the preservation of neuropathic pain (Figure 2). This process is because of most of the inflammatory mediators released by reactive microglia interacting with membrane receptors of nociceptive second-order projection neurons in the dorsal horn of the spinal cord, causing hyperexcitability and sensitization among them. ${ }^{47-50}$ It is important to mention that traumatic spinal cord injury also induces spinal microglial cell reactivation, which leads to an increase of inflammatory mediators and hyperexcitability in spinal nociceptive projection neurons. ${ }^{18}$ After microglial cell reactivation is produced by an injury in the nociceptive somatosensory system, a long-standing reactivation of spinal astrocytes occurs ( $>150$ days post-injury), inducing hypertrophy within (increase in vimentin and GFAP glial fibrillary acidic cytoskeleton proteins) and a release of inflammatory mediators that contribute to hyperexcitability and sensitization of nociceptive neurons in the dorsal horn of the spinal cord. ${ }^{47-51}$

On the other hand, neuropathic pain is also promoted by spinal cord injury. It is well known that spinal cord injury causes the astrocyte and microglial cell reactivation and the generation and release of several soluble factors such as cytokines (IL1, IL6 and
TNF-alpha), chemokines (CCL2) and prostaglandins (PGE2) that interact with nociceptive projection neurons and afferent primary nerve fibers at the dorsal horn of spinal cord segments located rostral and caudal to the lesion site, causing hyperexcitability of these nociceptive neurons and pain neurotransmission in the dorsal horn. Spinal cord injury also causes the necrotic death of astrocytes and neurons, with the release of neurotransmitters (glutamate) and potassium ion that also stimulates nociceptive projection neurons. ${ }^{52}$ Hyperalgesia and pain following spinal cord injury can result from maladaptive plastic changes throughout the neural axis, including supra-spinal structures. In line with these findings, it has been repeatedly shown that spinal cord injury is associated with increased activity, increased spike bursts and changes in glial activation in the thalamus. ${ }^{53-55}$

The thalamus is an important structure that mediates different components of pain: sensory discriminative (lateral pain pathway) and affective-motivational (medial pain pathway) components. Despite the fact that the thalamus has a key role in modulating nociceptive information, ${ }^{56}$ central sensitization and hyperexcitability of neurons from the spinothalamic pathway results not only in a greater stimulation of thalamic neurons via glutamate neurotransmission, ${ }^{57,58}$ which interacts with glutamatergic receptors (AMPA and NMDA) from thalamic neurons inducing depolarization, but also sensitization via calcium influx, as described above (Table 3). Some evidence on molecular neuroplasticity changes associated with peripheral and/or spinal cord injuries in the thalamus and other supra-spinal structures related with neuropathic pain has already been provided..$^{59}$ In line with this, chronic constriction injury (CCI) of the sciatic nerve induces an overexpression of constitutive isoforms Homer1b/c and Homer2a/b in the spinal dorsal horn and supra-spinal structures involved in nociception (prefrontal cortex and thalamus) that co-occurre with increases in their associated mGluRs and NR2 subunits of the NMDA receptor. These findings suggest that glutamatergic transmission in the ascending pain pathway related to neuropathic pain is mediated by Homer proteins. ${ }^{59}$

Several receptors have analgesic effects in models of neuropathic pain. Upregulation of thalamic nicotinic and cannabinoid receptors 
a

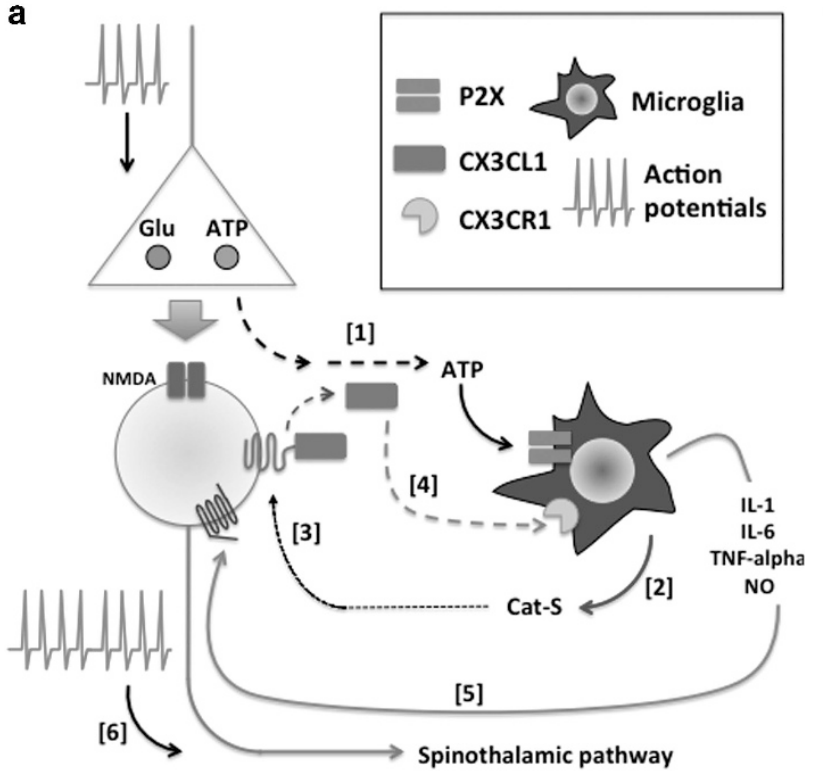

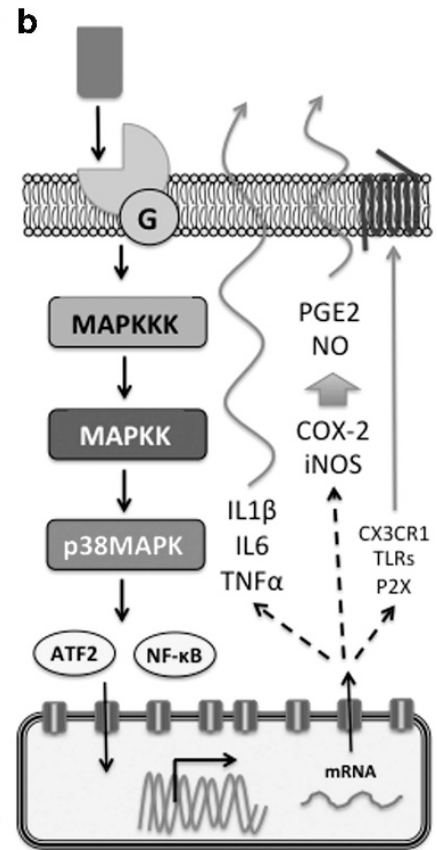

Figure 2 Schematic representation of microglia reactivation by neurotransmitters and neuromodulators released by afferent nociceptive neurons. (a) Hyperexcited afferent nociceptive neurons release not only glutamate but also ATP over nociceptive spinal cord neurons, causing their excitability. ATP also promotes the activation of spinal cord microglia cells by means of their binding with P2X receptors (e.g., P2X4 or P2X7) [1]. Activated microglia secrets cathepsin-S [2] that promotes the cleavage of fractalkine (CX3CL1), a glycoprotein expressed in the cell membrane of spinal cord nociceptive neurons [3]. Subsequently, biologically active fractalkine binds with fractalkine receptors (CX3CR1) located in the cell membrane of microglia cells [4], inducing the overexpression of proinflammatory agents such as cytokines and nitric oxide (NO), which also are able to stimulate spinal cord nociceptive neurons [5]. Overall, this feedback between neurons and microglia cells improves the hyperexcitability of spinal cord nociceptive neurons [6]. (b) When fractalkine (CX3CL1) binds with fractalkine receptors of microglia cells, it activates p38MAPK, signaling that activates the transcription factors ATF2 and NF-KB that translocate to the nucleus and initiate the transcription of target genes, including proinflammatory cytokines (e.g., IL-1 $\beta$, II6 and TNF- $\alpha$ ), proinflammatory enzymes (e.g., COX-2 and iNOS) that produce prostaglandins (PGE2) and NO and metabotropic receptors (e.g., CX3CR1 and TLRs, P2X). For further details, please see text.

has been reported after peripheral nerve injury models of neuropathic pain, ${ }^{60-62}$ suggesting that supra-spinal nicotinic and cannabinoid receptors in the thalamus may contribute to the modulation of neuropathic pain responses. On the other hand, $\mu$-opioid receptormediated G-protein activity was reduced in the thalamus of CCI mice, indicating an apparent desensitization in receptors from this region. ${ }^{63}$ A decrease of Na-K-Cl cotransporter-1 (NKCC1) and potassium chloride cotransporter-2 (KCC2) expression, implicated in the GABAergic/glycinergic transmission, has also been reported in the thalamus (ventral posterolateralnucleus) and primary somatosensory cortex (S1) after sciatic nerve section and suture in adult rats that showed mechanical and thermal hyperalgesia, suggesting that peripheral nerve injury induces neuropathic pain by reducing inhibitory inputs at thalamus and cortex. ${ }^{64}$

Neuropathic pain also causes neuroplasticity affecting glial cells located in supra-spinal centers. In line with this, thalamic microglial density increased in streptozotocin (STZ)-diabetic CD1 mice that showed tactile allodynia and thermal hypersensitivity, ${ }^{65}$ and in CCI-mice that also showed thermal hyperalgesia. ${ }^{66}$ Finally, an increase of IL- $1 \beta$ expression was observed in the thalamus after spared nerve injury in rats. ${ }^{67}$ Altogether, these findings suggest that the reactivation of microglia cells and secretion of inflammatory cytokines in the thalamus by peripheral nerve injuries facilitate excitation of pain thalamic neurons and neuropathic pain. These findings are in contrast with another study that showed that microglia was not activated in supra-spinal regions of the central nervous system, including the thalamus, the anterior cingulate cortex, prefrontal cortex, primary and secondary somatosensory cortex (S1 and S2), insular cortex, amygdala, hippocampus, periaqueductal gray (PAG) and rostral ventromedial medulla (RVM) in animals subjected to a peroneal nerve ligation. ${ }^{68}$

\section{MOLECULAR NEUROPLASTICITY OF THE DESCENDING INHIBITORY PAIN PATHWAY IN THE INJURED SOMATOSENSORY SYSTEM}

It is well known that several groups of brainstem neurons are related with nociceptive modulation, forming the called 'brainstem painmodulating system'. ${ }^{69}$ Descending control arises from a number of supra-spinal sites, including the midline PAG-RVM system, the more lateral and caudal dorsal reticular nucleus (DRt) and caudal ventrolateral medulla $(\mathrm{cVLM}) .^{70}$ The neurons from PAG do not project directly to the spinal cord. The main descending projection is the RVM that includes the nucleus raphe magnus and the adjacent reticular formation. RVM neurons receive a dense innervation from the PAG and project to the dorsal horn through the dorsolateral funiculus, forming synapses with spinal cord neurons of the dorsal horn, in both superficial and deep layers. ${ }^{6-71}$ The DRt is placed in the reticular formation medial to the spinal trigeminal nucleus, pars caudalis, lateral to the nucleus tractus solitarius, ventral to the cuneate nucleus and dorsal to the ventral reticular nucleus. DRt stimulation causes hyperalgesia in acute pain, whereas its lesion induces analgesia in both the acute and persistent pains. ${ }^{72,73}$ The descending pronociceptive fibers from the DRt nucleus establish putatively excitatory synaptic contacts upon lamina I neurons that project back to the DRt. Excitatory synaptic contacts also occur between DRt-projecting spinal 
a



b

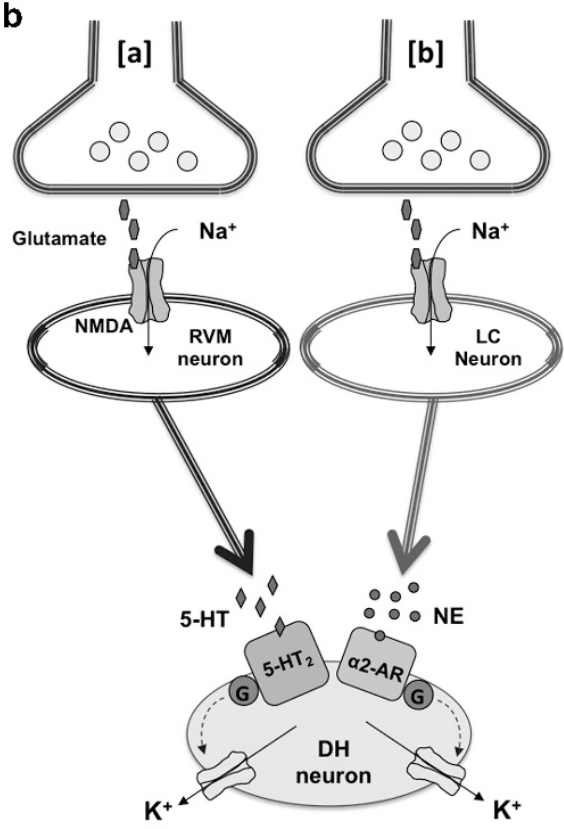

Figure 3 Schematic representation of two major brainstem descending nociceptive somatosensory pathways. (a) Nociceptive neurons located in the dorsal horn (DH) project their axons up to thalamic neurons forming not only the spinothalamic pathway [1] but also other nociceptive ascending pathways such as the spinobulbar pathway, which projects to neurons located in the ventrolateral reticular formation, dorsal reticular nucleus, nucleus tractus solitari and rostral ventromedial medulla (RVM) [2], the spinopontine pathway that projects to neurons from the parabranchial nuclei and locus coeruleus (LC) [3], and the spinomesencephalic pathways that project to neurons of periaqueductal gray matter (PAG) [4]. PAG neurons project their descending axons to neurons located in LC and RVM. Neurons located in the RVM and LC directly project their axons to the spinal DH, where the nociceptive input is initially processed. PAG neurons also receive input from forebrain structures including cerebral cortex, hypothalamus and amygdala. (b) Spinobulbar pathway (spino-RVM) [a] and spinopontine pathway (spino-LC) [b] release glutamate over RMV and LC neurons. In both groups of neurons, glutamate binds with NMDA receptors, causing an influx of sodium ions and depolarization of these neurons. At the dorsal horn, RVM neurons release serotonin (5-HT), whereas LC neurons release norepinephrine (NE) over the same neuron. Serotonin binds with $5-\mathrm{HT}_{2}$ receptors, whereas $\mathrm{NE}$ binds with alpha-2-adrenoreceptors, causing hyperpolarization of the $\mathrm{DH}$ neuron by the modulation of potassium ion channels. For more details, please see text.

cells and spinally projecting DRt neurons. ${ }^{74} \mathrm{cVLM}$ is one of the main inhibitory components of the endogenous pain modulatory system, and its stimulation induces analgesia in acute pain. ${ }^{74}$ The reticular formation known as cVLMlat, located in the most lateral part of the cVLM between the spinal trigeminal nucleus (pars caudalis) and the lateral reticular nucleus, appears to be the CVLM region responsible for pain modulation. The analgesia induced upon cVLMlat stimulation is more intense, ${ }^{75}$ and the neurons project to the spinal laminae involved in pain transmission (laminae I, IV, V and X) ${ }^{74,76}$ The cVLMlat also targets the dorsal horn indirectly through other components of the pain modulatory system, specifically through the pontine A5 noradrenergic cell group. ${ }^{74,77}$

Terminals of descending pathways originating in the rostroventral medulla (RVM) and other brainstem nuclei (for example, nucleus raphe magnus, A5, A6 and A7 nuclei) interact with afferent fibers, interneurons and projection neurons in the dorsal horn. ${ }^{78}$ Several neurotransmitters are involved in these descending pathways, but serotonin and noradrenaline are the main neurotransmitters. The predominant source of serotonergic input to the spinal cord arises within the vicinity of the RVM and, most prominently, from the nucleus raphe magnus. Serotonin causes hyperpolarization of afferent nociceptive fiber terminals and dorsal horn projection neurons when interacting with $5-\mathrm{HT}_{1}$ and $5-\mathrm{HT}_{2}$ receptors, and it produces excitation in spinal GABA-ergic interneurons when interacting with $5-\mathrm{HT}_{3}$ receptors. ${ }^{78}$ On the other hand, the spinal cord is innervated by both adrenergic cell clusters in medullary $\mathrm{C} 1$ and $\mathrm{C} 2$ nuclei and by noradrenergic nuclei localized in A5 and A6 (locus coeruleus) and the pontine A7 (subcoeruleus) regions. Similarly, noradrenaline causes hyperpolarization of projection neurons when interacting with $\alpha-2 \mathrm{~A}$ receptors and over terminals of primary afferent fibers when it interacts with $\alpha-2 \mathrm{~B} / \mathrm{C}$ receptors, whereas it induces excitation of dorsal horn inhibitory interneurons via $\alpha-1 \mathrm{~A}$ receptors ${ }^{78}$ (Figure 3 ).

Electrophysiological recordings in the RVM have revealed two types of neurons. One class of RVM neuron, the 'ON' cell, shows a burst of activity beginning just before withdrawal from a noxious stimulus. The other major cell class, the 'OFF' cell, has the opposite firing pattern, pausing during withdrawal from noxious heat. Several studies suggest that 'ON' cells facilitate, while 'OFF' cells inhibit, pain transmission. ${ }^{79-81}$

Several experimental models of neuropathic (for example, nerve ligation) and inflammatory pain have demonstrated that hyperexcitation of specific nociceptive and WDR neurons in the spinal cord causes the hyperexcitability and sensitization of RVM neurons that facilitate the descendent pain signaling toward a dorsal horn level in the spinal cord. ${ }^{82,83}$ In particular, in the RVM nucleus, a potentiating of the 'ON' neuron response and a decrease of the 'OFF' neuron response has been observed. 'ON' cells exert a pro-nociceptive effect, whereas 'OFF' cells produce an anti-nociceptive effect. The preferential activation of 'ON' cells located in RVM causes hyperalgesia, whereas hypoalgesia is achieved by the activation of RVM 'OFF' cells. ${ }^{80,82,84,85}$

It is well known that 'ON' cells showed not only mu opioid receptor $^{81}$ but also other receptors including cholecystokinin-B 

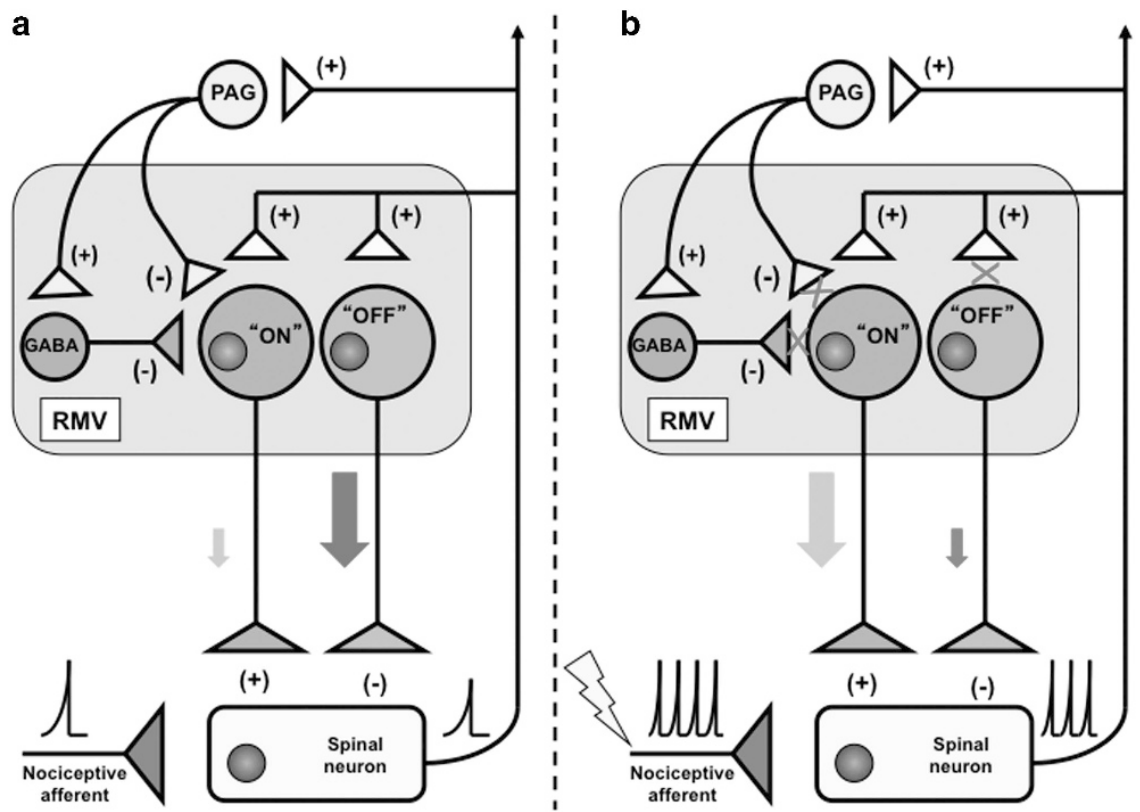

Figure 4 Schematic representation of activation/inactivation of 'ON' and 'OFF' neurons from RVM. (a) Under physiological conditions, the firing derived from nociceptors depolarizes spinal cord nociceptive neurons, and pain sensation travels through the spinothalamic pathway. At brainstem level, these action potentials stimulate PAG neurons and 'ON'/'OFF' neurons from RMV. Excited PAG neurons also stimulate GABAergic interneurons located in RMV and inhibit 'ON' neurons. Consequently, 'ON' neurons are inhibited, whereas 'OFF' neurons are excited, and the effect over the spinal nociceptive neuron is a decrease in the firing response. (b) After neuropathic pain caused by injuries in the peripheral and/or central nervous system, the hyperexcitability of spinal cord neurons causes changes in the expression of ion channels and receptors, and consequently 'ON' neurons are insensitive to inhibitory inputs from GABAergic interneurons and PAG neurons, whereas they become more sensitive to inputs from the spinothalamic pathway. In addition, these molecular changes also affect 'OFF' neurons that are insensitive to excitatory inputs from the spinothalamic pathway. Therefore, neuropathic pain results in a potentiation of 'ON' neuron inputs over spinal cord neurons that produce descent facilitation from RVM (for details see text).

receptor, NMDA/AMPA receptors, SP-NK1 receptors, brain-derived neurotrophic factor TrK-B receptors and TRPV1 receptors. ${ }^{86-90}$ PAG neurons release $\beta$-endorphin over 'ON'-RVM neurons causing hyperpolarization via $\mathrm{mu}$ opioid receptor, and the descending facilitation from 'ON' neurons is inhibited. ${ }^{83}$ In addition, the stimulation of TRPV1 receptor also inhibits 'ON'-RVM neurons (Figure 4). ${ }^{91}$

However, after neuropathic and/or inflammatory pain, the hyperexcitability of nociceptive ascending neurons also causes a sensitization of 'ON'-RVM neurons by overexpression of NMDA/AMPA, Trk-B and NK1 receptors, whereas mu opioid receptor expression decreases. Under these circumstances, 'ON'-RVM neurons do not respond to inhibitory signals from PAG, whereas they are highly stimulated by ascending inputs (Figure 4$)^{86,92,93}$ that release glutamate, SP and dynorphin over thalamic and brainstem neurons including 'ON'-RVM cells. $^{84-96}$ In summary, all these neurotransmitters released by nociceptive ascending neurons over 'ON'-RVM neurons cause their hyperexcitability (Figure 4$){ }^{97}$

Neuropathic and inflammatory pain also causes changes in PAG neurons. Under these circumstances, the hyperexcitability of nociceptive ascending neurons not only induces sensitization of PAG neurons causing overexpression of several receptors including NMDA/AMPA and SP/NK1 but also overexpression of glutamate and brain-derived neurotrophic factor. These PAG-brain-derived neurotrophic factor-positive neurons project their axons over the 'ON'-RVM neurons, enhancing their depolarization via Trk-B and NMDA/AMPA receptors. ${ }^{86}$

In summary, several independent lines of evidence suggest that both nociceptive ascending inputs and PAG-brain-derived neurotrophic factor neurons are related with the hyperexcitability of 'ON'-RVM neurons after neuropathic and inflammatory pain (Figure 4). It is well know that nociceptive ascending pathways include the spinothalamic, spinocervical, spinobulbar, spinopontine, spinomesencephalic, spinodiencephalic and spinothelencephalic pathways. ${ }^{98}$ Spinobulbar and spinomesencephalic pathways are ascending nociceptive pathways that project to RVM and PAG, respectively. ${ }^{98}$ Spinal cells projecting in the spino-RVM pathway predominate in laminae V, VII, VIII and X, whereas neurons of origin of the spino-PAG pathway are located in laminae I, IV-V, VI-VIII and the lateral spinal nucleus. ${ }^{98}$

Furthermore, 'OFF'-RVM neurons mainly express NMDA/AMPA ${ }^{69}$ and TRPV 199 receptors. Under physiological conditions, PAG neurons release glutamate over 'OFF'-RVM neurons, causing their depolarization via NMDA/AMPA receptors. Consequently, 'OFF'-RVM neurons produce an anti-nociceptive effect in the spinal neurons of dorsal horn. ${ }^{80}$ After neuropathic and/or inflammatory pain, the hyperexcitation of ascending nociceptive pathways, including spino-RMV and spino-PAG pathways, causes molecular changes of 'OFF'-RVM neurons such as an overexpression of GABA-A and kappa opioid receptors. ${ }^{69,100}$ Under these circumstances, 'OFF'-RVM neurons are more sensitive to the action of GABA released by RVM interneurons, which in turn are stimulated by ascending neurons from the spino-RVM pathway, and by $\beta$-endorphins released by PAG neurons, which in turn are excited by ascending neurons from the spino-PAG pathway. ${ }^{101}$ Altogether, these results suggest that after neuropathic and/or inflammatory pain 'OFF'-RVM neurons are hyperpolarized and their anti-nociceptive effect on spinal cord neurons is reduced (Figure 4).

On the other hand, several studies focusing on neuropathic pain (for example, chronic constriction injury) and inflammatory pain (for example, peripheral inflammation with carrageenan) showed an 
increase of microglial and astroglial reactivity in RVM, releasing several mediators that facilitate the excitation of 'ON'-RVM neurons and their excitatory effect on dorsal horn neurons. ${ }^{102-104}$

In summary, experimental evidence demonstrates that neuropathic pain triggers plastic changes in the descending pain modulatory pathway, which results eventually in ' $\mathrm{ON}$ ' cell activation and 'OFF cell inactivation from the PAG-RVM system, and RVM glial reactivation, which causes pain facilitation in the spinal cord.

\section{THERAPEUTIC APPROACHES IN NEUROPATHIC PAIN BASED ON THE NEUROPLASTICITY OF THE INJURED SOMATOSENSORY SYSTEM}

The overexpression of sodium and calcium voltage-gated ion channels, TRP, ASIC, hyperpolarization-activated cyclic nucleotide-gated channels, TrK-B, ROM, KOM, NK1, purinergic and glutamatergic receptors along with a decrease in endogenous inhibitory inputs and a spinal glia reactivation bring together the main molecular and cellular changes related to neuroplasticity of the injured nociceptive somatosensory system, responsible for triggering neuropathic pain. The use of pharmacological treatment specific to cellular and molecular targets of neuropathic pain constitutes a new therapeutic approach.

Several experimental studies have shown that the use of agonists and antagonists that selectively bind most of the molecular targets that are overexpressed in neuropathic pain would provide a promising new therapy for the treatment of neuropathic pain. In this sense, a first therapeutic approach involves the development and use of new 'antagonists and/or membrane receptor blockers' associated with neuropathic pain. Thus, the administration of H-Arg-15-15C, a TRPV1 selective antagonist, in peripheral inflammation models (for example, formalin, carrageenan Complete Freund's adjuvant) results in a significant reduction of allodynic responses. ${ }^{105}$ Similar results are obtained with the administration of AMG-517, another TRPV1 receptor antagonist. ${ }^{106}$ Moreover, the administration of isopentenyl pyrophosphate, TRPA1 and TRPV3 inhibitors also reduces mechanical and thermal hypersensitivity related to inflammatory processes. ${ }^{107}$ The use of TRPA1 channel inhibitors (for example, AP-18, A-967079, HC-030031 and Chembridge-5861528) reduces hyperalgesic and allodynic symptoms after a peripheral lesion produced by either nerve chronic constriction or inflammation. ${ }^{108}$ Blocking purinergic P2X receptors with A-740003 antagonists also reduces neuropathic pain induced by a peripheral inflammation. ${ }^{109}$ In CCI models, systemic administration of ZD7288 and Eugenol, two inhibitors of hyperpolarization-activated cyclic nucleotide-gated channels channels, produces a significant decrease in allodynic responses after nerve injury. ${ }^{10,111}$ Furthermore, a toxin named APETx2, obtained from a sea anemone Anthopleura elegantissina, is a potent selective antagonist of ASIC-3 receptors. Its experimental utilization has shown a significant decrease in painful symptoms related to muscle injuries, inflammatory lesions, visceral pain, migraine and postoperative pain. ${ }^{112}$ Alternative drugs or ASIC blockers are amiloride, A-317567, metallic ions $\left(\mathrm{Gd}^{3+}, \mathrm{Pb}^{2+}, \mathrm{Ni}^{2+}, \mathrm{Cd}^{2+}\right.$ and $\left.\mathrm{Cu}^{2+}\right)$ and divalent cations $\left(\mathrm{Ca}^{2+}, \mathrm{Mg}^{2+}\right.$ and $\left.\mathrm{Zn}^{2+}\right) .{ }^{113}$ In peripheral inflammation models, the administration of amiloride and benzamil also inhibits ASIC channels and produces, thus, a decrease in pain responses. ${ }^{114}$

A second therapeutic strategy against neuropathic pain lies in reducing hyperexcitability of the injured nociceptive somatosensory system by 'modulation of voltage-dependent and/or ligand-gated ion channels'. In this sense, in an arthritis experimental model, it has been shown that bisphosphonate compounds (for example, etidronate and alendronate) reduce the associated neuropathic pain. This antinociceptive effect could be reversed by glibenclamide and tolbutamide, which are ATP-gated potassium channel $\left(\mathrm{K}^{+}\right.$ATP channels) inhibitors. These results suggest that bisphosphonate compounds enhance the activation of $\mathrm{K}^{+}$ATP channels located in peripheral nociceptors, causing outward currents of potassium ions and hyperpolarization that result in an analgesic effect. ${ }^{115}$ Posterior to a CCI procedure, intrathecalcromakalim administration, a potassium channel-opening drug, also reduced thermal hyperalgesia and mechanical allodynia. ${ }^{116}$ In both CCI and inflammatory models, the administration of secondgeneration voltage-gated sodium channel inhibitors (for example, CDA54, QX-314, A-803467 and V102862) also alleviates hyperalgesia and allodynic symptoms. ${ }^{117}$

An alternative therapeutic approach used to reduce neuropathic pain consists of preventing the expression of ion channels in the plasma membrane of nociceptive neurons. In this sense, the development and administration of TAT-CBD3, a polypeptide that interferes with intracellular transportation of voltage-dependent calcium channel (Cav2.2), reduces hyperalgesia and allodynia responses, after a chronic nerve constriction injury. ${ }^{118}$

\section{CONCLUSIONS}

Pain triggered by traumatic lesions, tissular inflammation and/or peripheral nerve injury leads to sodium and calcium ions influx in the nociceptors, resulting in depolarization and sensitization, respectively. Peripheral sensitization activates intracellular cascades that induce ionic channel and membrane receptor phosphorylation, subsequently enhancing nociceptor sensitivity to algogenic mediators, and also molecular changes including overexpression of voltage-gated ion channels, receptors to algogenic mediators and neurotransmittersneuromodulators. All these changes cause hyperexcitability of peripheral nociceptors that in turn release glutamate and other neurotransmitters over nociceptive neurons located in the dorsal horn of the spinal cord. Hyperexcitation of projection neurons of the dorsal horn results in hyperexcitation of ascending nociceptive pathways, including the spinothalamic pathway that projects pain to both the thalamus and the cortex, but also spino-RVM and spino-PAG pathways that facilitate the excitation of 'ON'-RVM neurons and the hyperpolarization of 'OFF'-RVM neurons. The molecular changes that occurred in PAG and RVM neurons after neuropathic and/or inflammatory pain result in a strenghthening of the descendent excitatory pathway mediated by 'ON'-RVM neurons, and an inhibition of the descending inhibitory pathway of pain, mediated by 'OFF'-RVM neurons. Molecular studies in plastic changes in the nociceptive somatosensory system enable the development of new pharmacological treatments against pain, which will be more specific and effective than classical drug treatments. Although research efforts currently focus on this point, additional research may be necessary to further explore potential therapeutic targets in pain involved in the neuroplasticity changes of neuropathological pathways of the injured somatosensory system.

\section{CONFLICT OF INTEREST}

The authors declare no conflict of interest.

\section{ACKNOWLEDGEMENTS}

The present work was funded by Accions Singulars de R+D (Sing 12/17) from the Vice-Chancellorship in Research of the University of Girona (Vicerectorat de Recerca de la Universitat de Girona), Girona, Spain. We also thank Dr Mariano Gacto Sánchez for his support with the English-language editing. 
1 Merskey $\mathrm{H}$, Lindblom U. Pain terms a current list with definitions and notes on usage. In: Merskey H, Bogduk N (eds). Classification of Chronic Pain, 2nd edn. IASP Press: Seattle, WA, USA, 1994, pp 207-213.

2 Jensen TS, Baron R, Haanpää M, Kalso E, Loeser JD, Rice ASC et al. A new definition of neuropathic pain. Pain 2011; 152: 2204-2205.

3 Haanpää M, Attal N, Backonja M, Baron R, Bennett M, Bouhassira D et al. NeuPSIG guidelines on neuropathic pain assessment. Pain 2011; 152: 14-27.

4 Woolf CJ, Mannion RJ. Neuropathic pain: aetiology symptoms mechanisms and management. Lancet 1999; 353: 1959-1964.

5 Dworkin RH, Backonja M, Rowbotham MC, Allen RR, Argoff CR, Bennett GJ et al. Advances in neuropathic pain: diagnosis mechanisms and treatment recommendations. Arch Neurol 2003; 60: 1524-1534.

6 Kehlet $\mathrm{H}$, Jensen TS, Woolf CJ. Persistent postsurgical pain: risk factors and prevention. Lancet 2006; 367: 1618-1625.

7 Bennett MI, Rayment C, Hjermstad M, Aass N, Caraceni A, Kaasa S. Prevalence and aetiology of neuropathic pain in cancer patients: a systematic review. Pain 2012; 153: 359-365.

8 Drew GM, Mitchell VA, Vaughan CW. Postsynaptic actions of substance $P$ on rat periaqueductal grey neurons in vitro. Neuropharmacology 2005; 49: 587-595.

9 Ciaramitaro P, Mondelli M, Logullo F, Grimaldi S, Battiston B, Sard A et al. Traumatic peripheral nerve injuries: epidemiological findings neuropathic pain and quality of life in 158 patients. J Peripher Nerv Syst 2010; 15: 120-127.

10 Siddall PJ, Loeser JD. Pain following spinal cord injury. Spinal Cord 2001; 39: 63-73.

11 Dijkers M, Bryce T, Zanca J. Prevalence of chronic pain after traumatic spinal cord injury: a systematic review. J Rehab Res Dev 2009; 46: 13-30.

12 Modirian E, Pirouzi P, Soroush M, Karbalaei-Esmaeili S, Shojaei H, Zamani H. Chronic pain after spinal cord injury: results of a long-term study. Pain Med 2010; 11: 1037-1043.

13 Cripps RA, Lee BB, Wing P, Weerts E, Mackay J, Brown D. A global map for traumatic spinal cord injury epidemiology: towards a living data repository for injury prevention. Spinal Cord 2011; 49: 493-501.

14 McCarberg BH, Billington R. Consequences of neuropathic pain: quality of life issues and associated costs. Am J Manag Care 2006; 12: S263-S268.

15 Zimmermann M. Pathobiology of neuropathic pain. Eur J Pharmacol 2001; 429: 23-37.

16 Campbell JN, Meyer RA. Mechanisms of neuropathic pain. Neuron 2006; 52: 77-92.

17 Gold MS, Gebhart GF. Nociceptor sensitization in pain pathogenesis. Nat Med 2010; 16: $1248-1257$

18 Xifró X, Puig T, Boadas-Vaello P. Diagnóstico y tratamiento farmacológico del dolor neuropático del lesionado medular: del laboratorio a la clínica. Med Clin 2013; 140: 175-181.

19 Verdú E, Navarro X. Fisiología de la transmisión nociceptiva en el SNC. In: Aliaga A, Baños JE, Barutell C, Molet J, Rodríguez A (eds). Tratamiento del dolor: teoría y práctica, 3rd edn. Publicaciones Permanyer: Barcelona, 2009, pp 27-327-213.

20 Verdú E, Navarro X, Baños JE. Neuroquímica funcional del dolor. In: Aliaga A, Baños JE, Barutell C, Molet J, Rodríguez A (eds). Tratamiento del dolor: teoría y práctica, 2nd edn. Publicaciones Permanyer: Barcelona, 2002, pp 27-42.

21 Mense S. Anatomy of nociceptors. In: Basbaum Al, Bushnell MC (eds). Science of Pain. Elsevier: Amsterdam, 2009, pp 11-41.

22 Aurilio C, Pota V, Pace MC, Passavanti MB, Barbarisi M. Ionic channels and neuropathic pain: physiopathology and applications. J Cell Physiol 2008; 215: 8-14.

23 Cregg R, Momin A, Rugiero F, Wood JN, Zhao J. Pain channelopathies. J Physiol 2010; 588: 1897-1904.

24 Zoga V, Kawano T, Liang MY, Bienengraeber M, Weihrauch D, McCallum B et al. KATP channel subunits in rat dorsal root ganglia: alterations by painful axotomy. $\mathrm{Mol}$ Pain 2010; 6: 6 .

25 Sarantopoulos C, McCallum B, Sapunar D, Kwok WM, Hogan Q. ATPsensitive potassium channels in rat primary afferent neurons: the effect of neuropathic injury and gabapentin. Neurosci Lett 2003; 343: 185-189.

26 Taylor BK. Pathophysiologic mechanisms of neuropathic pain. Curr Pain Headache Rep 2001; 5: 151-161.

27 Taylor BK. Spinal inhibitory neurotransmission in neuropathic pain. Curr Pain Headache Rep 2009; 13: 208-214.

28 Chizh B, Illes P. P2X receptors and nociception. Pharmacol Rev 2000; 53: 553-568.

29 Yu Y, Lundeberg T, Yu LC. Role of calcitonin gene-related peptide and its antagonist on the evoked discharge frequency of wide dynamic range neurons in the dorsal horn of the spinal cord in rats. Regul Pept 2012; 103: 23-27.

$30 \mathrm{Gu}$ JG. P2X receptor-mediated modulation of sensory transmission to the spinal cord horn. Neuroscientist 2003; 9: 370-378.

31 Neugebauer V. Metabotropic glutamate receptors-imporant modulators of nociception and pain behaviour. Pain 2002; 98: 1-8.

32 Ruscheweyh R, Sandkühler J. Role of kainate receptors in nociception. Brain Res Rev 2002; 40: 215-222.

33 Polgár E, Al-Khater KM, Shehab S, Watanabe M, Todd AJ. Large projection neurons in lamina I of the rat spinal cord that lack the neurokinin 1 receptor are densely innervated by VGLUT2-containing axons and possess GluR4-containing AMPA receptors. J Neurosci 2008; 28: 13150-13160.

34 Polgár E, Watanabe M, Hartmann B, Grant SG, Todd AJ. Expression of AMPA receptor subunits at synapses in laminae I-III of the rodent spinal cord horn. Mol Pain 2008; 4: 5 .
35 Tong CK, Kaftan EJ, Macdermott AB. Functional identification of NR2 subunits contributing to NMDA receptors on substance $P$ receptor-expressing dorsal horn neurons. Mol Pain 2008; 4: 44

36 Doolen S, Blake CB, Smith BN, Taylor BK. Peripheral nerve injury increases glutamate-evoked calcium mobilization in adult spinal cord neurons. Molecular Pain 2012; 8: 56.

37 Ultenius C, Linderoth B, Meyerson BA, Wallin J. Spinal NMDA receptor phosphorylation correlates with the presence of neuropathic signs following peripheral nerve injury in the rat. Neurosci Lett 2006; 399: 85-90.

38 Aronica E, Catania MV, Geurts J, Yankaya B, Troost D. Immunohistochemical localization of group I and II metabotropic glutamate receptors in control and amyotrophic lateral sclerosis human spinal cord: upregulation in reactive astrocytes. Neuroscience 2001; 105: 509-520.

39 Hansson E, Ronnback L. Altered neuronal-glial signaling in glutamatergic transmission as a unifying mechanism in chronic pain and mental fatigue. Neurochemical Res 2004; 29: 989-996.

40 Pocock JM, Kettenmann H. Neurotransmitter receptors on microglia. Trends Neurosci 2007; 30: 527-535.

41 Schomberg D, Olson JK. Immune responses of microglia in the spinal cord: contribution to pain states. Exp Neurol 2012; 234: 262-270.

42 Cao J, Wang JS, Ren XH, Zang WD. Spinal sample showing p-JNK and P38 associated with the pain signaling transduction of glial cell in neuropathic pain. Spinal Cord 2015; 53: 92-97.

43 Zhuo M, Wu G, Wu LJ. Neuronal and microglial mechanisms of neuropathic pain. Mol Brain 2011; 4: 31 .

44 Verge GM, Milligan ED, Maier SF, Watkins LR, Naeve GS, Foster AC. Fractalkine (CX3CL1) and fractalkine receptor (CX3CR1) distribution in spinal cord and dorsal root ganglia under basal and neuropathic pain conditions. Eur J Neurosci 2004; 20: $1150-1160$.

45 Zhuang ZY, Kawasaki Y, Tan PH, Wen YR, Huang J, Ji RR. Role of the CX3CR1/p38 MAPK pathway in spinal microglia for the development of neuropathic pain following nerve injury-induced cleavage of fractalkine. Brain Behav Immun 2007; 21: 642-651

46 Clark AK, Malcangio M. Microglial signalling mechanisms: Cathepsin S and Fractalkne. Exp Neurol 2012; 234: 283-292.

47 Kawasaki Y, Zhang L, Cheng JK, Ji RR. Cytokine mechanisms of central sensitization: distinct and overlapping role of interleukin-1beta interleukin- 6 and tumor necrosis factor-alpha in regulating synaptic and neuronal activity in the superficial spinal cord. J Neurosci 2008; 28: 5189-5194.

48 Gao YJ, Zhang L, Samad OA, Suter MR, Yasuhiko K, Xu ZZ et al. JNK-induced MCP-1 production in spinal cord astrocytes contributes to central sensitization and neuropathic pain. J Neurosci 2009; 29: 4096-4108.

49 Zhang RX, Li A, Liu B, Wang L, Ren K, Zhang H et al. IL-1ra alleviates inflammatory hyperalgesia through preventing phosphorylation of NMDA receptor NR-1 subunit in rats. Pain 2008; 135: 232-239.

50 Zhang RX, Liu B, Li A, Wang L, Ren K, Qiao JT et al. Interleukin 1beta facilitates bone cancer pain in rats by enhancing NMDA receptor NR-1 subunit phosphorylation. Neuroscience 2008; 154: 1533-1538.

51 Gao YJ, Ji RR. Targeting astrocyte signaling for chronic pain. Neurotherapeutics 2010; 7: 482-493.

52 Boadas-Vaello $\mathrm{P}$, Xifró X, Teresa Puig T. Physiopathology of neuropathic pain following spinal cord injury: new management strategies. In: Rider AL (ed.). Neuropathicpain: Risk Factors Types and Management Strategies, 1st edn. Nova Science Publishers: New York, 2014, pp 71-112.

53 Lenz FA, Tasker RR, Dostrovsky JO, Kwan HC, Gorecki J, Hirayama T et al. Abnormal single-unit activity recorded in the somatosensory thalamus of a quadriplegic patient with central pain. Pain 1987; 31: 225-236.

54 Wang G, Thompson S. Maladaptive homeostatic plasticity in a rodent model of central pain syndrome: thalamic hyperexcitability after spinothalamic tract lesions. J Neurosci 2008; 28: 11959-11969.

55 Masri R, Keller A. Chronic pain following spinal cord injury. Adv Exp Med Biol 2012; 760: 74-88.

56 Ab Aziz CB, Ahmad AH. The role of the thalamus in modulating pain. Malays J Med Sci 2006; 13: 11-18.

57 Eaton SA, Salt TE. Thalamic NMDA receptors and nociceptive sensory synaptic transmission. Neurosci Lett 1990; 110: 297-302.

58 Bordi F, Quartaroli M. Modulation of nociceptive transmission by NMDA/glycine site receptor in the ventroposterolateral nucleus of the thalamus. Pain 2000; 84: 213-224.

59 Obara I, Goulding SP, Hu JH, Klugmann M, Worley PF, Szumlinski KK. Nerve injury-induced changes in Homer/glutamate receptor signaling contribute to the development and maintenance of neuropathic pain. Pain 2013; 154: 1932-1945.

60 Siegling A, Hofmann HA, Denzer D, Mauler F, De Vry J. Cannabinoid CB(1) receptor upregulation in a rat model of chronic neuropathic pain. Eur J Pharmacol 2001; 415: R5-R7.

61 Ueda M, lida $Y$, Tominaga A, Yoneyama T, Ogawa M, Magata $Y$ et al. Nicotinic acetylcholine receptors expressed in the ventralposterolateral thalamic nucleus play an important role in anti-allodynic effects. Br J Pharmacol 2010; 159: 1201-1210.

62 Knerlich-Lukoschus F, Noack M, von der Ropp-Brenner B, Lucius R, Mehdorn HM, Held-Feindt J. Spinal cord injuries induce changes in cb1 cannabinoid receptor and c-c chemokine expression in brain areas underlying circuitry of chronic pain conditions. J Neurotrauma 2011; 28: 619-634. 
63 Hoot MR, Sim-Selley LJ, Selley DE, Scoggins KL, Dewey WL. Chronic neuropathic pain in mice reduces $\mu$-opioid receptor-mediated $\mathrm{G}$-protein activity in the thalamus. Brain Res 2011; 1406: 1-7.

64 Mòdol L, Cobianchi S, Navarro X. Prevention of NKCC1 phosphorylation avoids downregulation of KCC2 in central sensory pathways and reduces neuropathic pain after peripheral nerve injury. Pain 2014; 155: 1577-1590.

65 Toth CC, Jedrzejewski NM, Ellis CL, Frey WH 2nd. Cannabinoid-mediated modulation of neuropathic pain and microglial accumulation in a model of murine type I diabetic peripheral neuropathic pain. Mol Pain 2010; 6: 16

66 LeBlanc BW, Zerah ML, Kadasi LM, Chai N, Saab CY. Minocycline injection in the ventral posterolateral thalamus reverses microglial reactivity and thermal hyperalgesia secondary to sciatic neuropathy. Neurosci Lett 2011; 498: 138-142.

67 Apkarian AV, Lavarello S, Randolf A, Berra HH, Chialvo DR, Besedovsky $\mathrm{HO}$ et al. Expression of IL-1 $\beta$ in supraspinal brain regions in rats with neuropathic pain. Neurosci Lett 2006; 407: 176-181.

68 Zhang F, Vadakkan KI, Kim SS, Wu LJ, Shang Y, Zhuo M. Selective activation of microglia in spinal cord but not higher cortical regions following nerve injury in adult mouse. Mol Pain 2008; 4: 15.

69 Heinricher MM, Ingram SL. The brainstem and nociceptive modulation. In Basbaum AI, Bushnell MC (eds). Science of Pain. Elsevier: Amsterdam, 2009, pp 594-626.

70 Heinricher MM, Tavares I, Leith JL, Lumb BM. Descending control of nociception: specificity, recruitment and plasticity. Brain Res Rev 2009; 60: 214-225.

71 Fields $\mathrm{HL}$, Heinricher MM. Anatomy and physiology of a nociceptive modulatory system. Philos Trans $R$ Soc Lond B Biol Sci 1985; 308: 361-374.

72 Almeida A, Tjølsen A, Lima D, Coimbra A, Hole K. The medullary dorsal reticular nucleus facilitates acute nociception in the rat. Brain Res Bull 1996; 39: 7-15.

73 Almeida A, Størkson R, Lima D, Hole K, Tiølsen A. The medullary dorsal reticular nucleus facilitates pain behavior induced by formalin in the rat. Eur J Neurosci 1999 11: 110-122.

74 Tavares I, Lima D. From neuroanatomy to gene therapy: searching for new ways to manipulate the supraspinal endogenous pain modulatory system. J Anat 2007; 211 261-268.

75 Ossipov MH, Gebhart GF. Opioid, cholinergic and alpha-adrenergic influences on the modulation of nociception from the lateral reticular nucleus of the rat. Brain Res 1986; 384: 282-293.

76 Tavares I, Almeida A, Esteves F, Lima D, Coimbra A. The caudal ventrolatera medullary reticular formation is reciprocally connected with the spinal cord. Soc Neurosci Abstract 1998; 24: 1132

77 Tavares I, Lima D, Coimbra A. The ventrolateral medulla of the rat is connected with the spinal cord dorsal horn by an indirect descending pathway relayed in the A noradrenergic cell group. J Comp Neurol 1996; 374: 84-95.

78 Millan MJ. Descending control of pain. Prog Neurobiol 2002; 66: 355-474.

79 Fields HL, Heinricher MM, Mason P. Neurotransmitters in nociceptive modulatory circuits. Annu Rev Neurosci 1991; 14: 219-245.

80 Heinricher MM, Tortorici V. Interference with GABA transmission in the rostral ventromedial medulla: disinhibition of off-cells as a central mechanism in nociceptive modulation. Neuroscience 1994; 63: 533-546.

81 Fields HL. Painmodulation: expectation, opioid analgesia and virtual pain. Prog Brain Res 2000; 122: 245-253.

82 Carlson JD, Maire JJ, Martenson ME, Heinricher MM. Sensitization of pain-modulating neurons in the rostral ventromedial medulla after peripheral nerve injury. $J$ Neurosci 2007; 27: 13222-13231.

83 Ossipov MH, Porreca F. Neuropathic pain: basic mechanisms. In: Basbaum Al Bushnell MC (eds). Science of Pain. Elsevier: Amsterdam, 2009, pp 833-864.

84 Heinricher MM, Neubert MJ. Neural basis for the hyperalgesic action of cholecystokinin in the rostral ventromedial medulla. J Neurophysiol 2004; 92: 1982-1989.

85 Khasabov SG, Brink TS, Schupp M, Noack J, Simone DA. Changes in response properties of rostral ventromedial medulla neurons during prolonged inflammation: modulation by neurokinin-1 receptors. Neuroscience 2012; 224: 235-248.

86 Guo W, Robbins MT, Wei F, Zou S, Dubner R, Ren K. Supraspinal brain-derived neurotrophic factor signaling: a novel mechanism for descending pain facilitation. J Neurosci 2006; 26: 126-137.

87 Budai D, Khasabov SG, Mantyh PW, Simone DA. NK-1 receptors modulate the excitability of ON cells in the rostral ventromedial medulla. J Neurophysiol 2007; 97 1388-1395.

88 Zhang W, Gardell S, Zhang D, Xie JY, Agnes RS, Badghisi H et al. Neuropathic pain is maintained by brainstem neurons co-expressing opioid and cholecystokinin receptors. Brain 2009; 132: 778-787.

89 Da Silva LF, Desantana JM, Sluka KA. Activation of NMDA receptors in the brainstem rostral ventromedial medulla and nucleus reticularis gigantocellularis mediates mechanical hyperalgesia produced by repeated intramuscular injections of acidic saline in rats. J Pain 2010; 11: 378-387.

90 Price TJ, Dussor G. AMPK: An emerging target for modification of injury-induced pain plasticity. Neurosci Lett 2013; 557: 9-18.

91 Palazzo E, Luongo L, de Novellis V, Berrino L, Rossi F, Maione S. Moving towards supraspinal TRPV1 receptors for cronic pain relief. Mol Pain 2010; 6: 66.

92 Miki K, Zhou QQ, Guo W, Guan Y, Terayama R, Dubner R et al. Changes in gene expression and neuronal phenotype in brain stem pain modulatory circuitry after inflammation. J Neurophysiol 2002; 87: 750-760.

93 Lagraize SC, Guo W, Yang K, Wei F, Ren K, Dubner R. Spinal cord mechanims mediating behavioral hyperalgesia induced by neurokinin-1 tachykinin receptor activation in the rostral ventromedial medulla. Neuroscience 2010; 171: 1341-1356.

94 Noguchi K, Ruda MA. Gene regulation in an ascending nociceptive pathway: inflammation-induced increase in preprotachykinin mRNA in rat lamina I spinal projection neurons. J Neurosci 1992; 12: 2563-2572.

95 Taketa Y, Niikura K, Kobayashi Y, Furuya M, Shimizu T, Narita M et al. Direct evidence for the ongoing brain activation by enhanced dynorphinergic system in the spinal cord under inflammatory noxious stimuli. Anesthesiology 2010; 112: 418-431.

96 Hemmings BA, Restuccia DF. PI3K-PKB/Akt Pathway. Cold Spring Harb Perspect Biol 2012; 4: 3-5.

97 Zhang L, Hammond DL. Substance P enhances excitatory synaptic transmission on spinally projecting neurons in the rostral ventromedial medulla after inflammatory injury. J Neurophysiol 2009; 102: 1139-1151.

98 Lima D. Ascending pathways: anatomy and physiology. In: Basbaum Al, Bushnell MC (eds). Science of Pain. 1st edn. Academic Press-Elsevier: Oxford, 2009, pp 477-526.

99 Palazzo E, Rossi F, Maione S. Role of TRPV1 receptors in descending modulation of pain. Mol Cell Endocrinol 2008; 286S: S79-S83.

100 Gutstein HB, Mansour A, Watson SJ, Akil H, Fields HL. Mu and kappa opioid receptors in periaqueaductalgray and rostral ventromedial medulla. Neuroreport 1998; 9: 1777-1781.

101 Satoh M, Minami M. Molecular pharmacology of the opioid receptors. Pharmacol Ther 1995; 68: 343-364.

102 Guo W, Wang H, Watanabe M, Shimizu K, Zou S, LaGraize SC et al. Glial-cytokineneuronal interactions underlying the mechanims of persistent pain. J Neurosci 2007; 27: 6006-6018.

103 Roberts J, Ossipov MH, Porreca F. Glial activation in the rostroventromedial medulla promotes descending facilitation to mediate inflammatory hypersensitivity. Eur $J$ Neurosci 2009; 30: 229-241.

104 Wei F, Guo W, Zou S, Ren K, Dubner R. Supraspinal glial-neuronal interactions contribute to descending pain facilitation. J Neurosci 2008; 28: 10482-10495.

105 García-Martínez C, Fernández-Carvajal A, Valenzuela B, Gomis A, Van Den Nest W, Ferroni $S$ et al. Design and characterization of a noncompetitive antagonist of the transient receptor potential vanilloidsubunit 1 channel with in vivo analgesic and anti-inflammatory activity. J Pain 2006; 7: 735-746.

106 Cui M, Honore P, Zhong C, Gauvin D, Mikusa J, Hernandez G et al. TRPV1 receptors in the CNS play a key role in broad-spectrum analgesia of TRPV1 antagonists. J Neurosci 2006; 26: 9385-9393.

107 Bang S, Yoo S, Yang TJ, Cho H, Hwang SW. Isopentenyl pyrophosphate is a novel antinociceptive substance that inhibits TRPV3 and TRPA1 ion channels. Pain 2011; 152: $1156-1164$

108 Andrade EL, Meotti FC, Calixto JB. TRPA1 antagonists as potential analgesic drugs. Pharmacol Ther 2012; 133: 189-204.

109 Honore P, Donnelly-Roberts D, Namovic MT, Hsieh G, Zhu CZ, Mikusa JP et al. A-740003 [N-(1-\{[(Cyanoimino)(5-quinolinylamino)methyl]amino\}-22-dimethylpropyl)2-(34dimethoxyphenyl)acetamide] a novel and selective P2X7 receptor antagonist dose-dependently reduces neuropathic pain in the rat. J Pharmacol Exp Ther 2006; 319: 1376-1385.

110 Takasu K, Ono H, Tanabe M. Spinal hyperpolarization-activated cyclic nucleotidegated cation channels at primary afferent terminals contribute to chronic pain. Pain 2010; 151: 87-96.

111 Yeon KY, Chung G, Kim YH, Hwang JH, Davies AJ, Park MK et al. Eugenol reverses mechanical allodynia after peripheral nerve injury by inhibiting hyperpolarizationactivated cyclic nucleotide-gated (HCN) channels. Pain 2011; 152: 2108-2116.

112 Wu WL, Cheng CF, Sun WH, Wong CW, Chen CC. Targeting ASIC3 for pain anxiety and insulin resistance. Pharmacol Ther 2012; 134: 127-138.

113 Deval E, Gasull X, Noël J, Salinas M, Baron A, Diochot S et al. Acid-sensing ion channels (ASICs): pharmacology and implication in pain. Pharmacol Ther 2010; 128: 549-558.

114 Rocha-González HI, Herrejon-Abreu EB, López-Santillán FJ, García-López BE, Murbartián J, Granados-Soto V. Acid increases inflammatory pain in rats: effect of local peripheral ASICs inhibitors. Eur J Pharmacol 2009; 603: 56-61.

115 Kawabata A, Kawao N, Hironaka Y, Ishiki T, Matsunami M, Sekiguchi F. Antiallodynic effect of etidronate a bisphosphonate in rats with adjuvant-induced arthritis: involvement of ATP-sensitive $\mathrm{K}^{+}$channels. Neuropharmacology 2006; 51: 182-190.

116 Wu XF, Liu WT, Liu YP, Huang ZJ, Zhang YK, Song XJ. Reopening of ATP-sensitive potassium channels reduces neuropathic pain and regulates astroglial gap junctions in the rat spinal cord. Pain 2011; 152: 2605-2615.

117 Clare JJ. Targeting voltage-gated sodium channels for pain therapy. Expert Opin Investig Drugs 2010; 19: 45-62.

118 Wilson SM, Brittain JM, Piekarz AD, Ballard CJ, Ripsch MS, Cummins TR et al. Further insights into the antinociceptive potential of a peptide disrupting the N-type calcium channel-CRMP-2 signaling complex. Channels 2011; 5: 449-456.

119 Lai J, Hunter JC, Porreca F. The role of voltage-gated sodium channels in neuropathic pain. Curr Opin Neurobiol 2003; 13: 291-297.

120 Cummins TR, Sheets PL, Waxman SG. The roles of sodium channels in nociception: implications for mechanisms of pain. Pain 2007; 131: 243-257.

121 Wood JN, Boorman JP, Okuse K, Baker MD. Voltage-gated sodium channels and pain pathways. J Neurobiol 2004; 61: 55-71.

122 Lampert A, O'Reilly AO, Reeh P, Leffler A. Sodium channelopathies and pain. Pflugers Arch 2010; 460: 249-263.

123 Berger JV, Deumens R, Goursaud S, Schäfer S, Lavand'homme P, Joosten EA et al. Enhanced neuroinflammation and pain hypersensitivity after peripheral nerve injury in rats expressing mutated superoxide dismutase 1. J Neuroinflammation 2011; 8: 33. 
124 Cao YQ. Voltage-gated calcium channels and pain. Pain 2006; 126: 5-9.

125 Jiang YQ, Sun Q, Tu HY, Wan Y. Characteristics of HCN channels and their participation in neuropathic pain. Neurochem Res 2008; 33: 1979-1989.

126 Emery EC, Young GT, McNaughton PA. HCN2 ion channels: an emerging role as the pacemakers of pain. Trends Pharmacol Sci 2012; 33: 456-463.

127 Bianchi L, Driscoll M. Protons at the gate: DEG/ENaC ion channels help us feel and remember. Neuron 2002; 34: 337-340.

128 Lingueglia E. Acid-sensing ion channels in sensory perception. J Biol Chem 2007; 282: 17325-17329.

129 Ding Y, Cesare P, Drew L, Nikitaki D, Wood JN. ATP P2X receptors and pain pathways. J Auton Nerv Syst 2000; 81: 289-294.

130 Tsuda M, Ueno S, Inoue K. Evidence for the involvement of spinal endogenous ATP and $\mathrm{P} 2 \mathrm{X}$ receptors in nociceptive responses caused by formalin and capsaicin in mice. Br J Pharmacol 1999; 128: 1497-1504.

131 Jara-Oseguera A, Simon SA, Rosenbaum T. TRPV1: on the road to pain relief. Curr Mol Pharmacol 2008; 1: 255-269.

132 Stucky CL, Dubin AE, Jeske NA, Malin SA, McKemy DD, Story GM. Roles of transient receptor potential channels in pain. Brain Res Rev 2009; 60: 2-23.

133 Hains BC, Saab CY, Klein JP, Craner MJ, Waxman SG. Altered sodium channel expression in second-order spinal sensory neurons contributes to pain after peripheral nerve injury. J Neurosci 2004; 24: 4832-4839.

134 Spicarova D, Nerandzic V, Palecek J. Modulation of spinal cord synaptic activity by tumor necrosis factor $\alpha$ in a model of peripheral neuropathy. J Neuroinflammation 2001; 8: 177 .

$135 \mathrm{Li} \mathrm{CY,} \mathrm{Song} \mathrm{YH,} \mathrm{Higuera} \mathrm{ES,} \mathrm{Luo} \mathrm{ZD.} \mathrm{Spinal} \mathrm{dorsal} \mathrm{horn} \mathrm{calcium} \mathrm{channel}$ alpha2delta-1 subunit upregulation contributes to peripheral nerve injury-induced tactile allodynia. J Neurosci 2004; 24: 8494-8499.

136 Boroujerdi A, Kim HK, Lyu YS, Kim DS, Figueroa KW, Chung JM et al. Injury discharges regulate calcium channel alpha-2-delta-1 subunit upregulation in the dorsal horn that contributes to initiation of neuropathic pain. Pain 2008; 139: 358-366.

137 Chen SR, Cai YQ, Pan HL. Plasticity and emerging role of BKCa channels in nociceptive control in neuropathic pain. J Neurochem 2009; 110: 352-362.

138 Luo H, Cheng J, Han JS, Wan Y. Change of vanilloid receptor 1 expression in dorsal root ganglion and spinal dorsal horn during inflammatory nociception induced by complete Freund's adjuvant in rats. Neuroreport 2004; 15: 655-658.
139 Wu LJ, Duan B, Mei YD, Gao J, Chen JG, Zhuo M et al. Characterization of acid-sensing ion channels in dorsal horn neurons of rat spinal cord. J Biol Chem 2004; 279: 43716-43724.

140 Galan A, Laird JM, Cervero F. In vivo recruitment by painful stimuli of AMPA receptor subunits to the plasma membrane of spinal cord neurons. Pain 2004; 112: 315-323.

141 Coull JA, Boudreau D, Bachand K, Prescott SA, Nault F, Sík A et al. Trans-synaptic shift in anion gradient in spinal lamina I neurons as a mechanism of neuropathic pain. Nature 2003; 424: 938-942.

142 Lu Y, Zheng J, Xiong L, Zimmermann M, Yang J. Spinal cord injury-induced attenuation of GABAergic inhibition in spinal dorsal horn circuits is associated with down-regulation of the chloride transporter KCC2 in rat. J Physiol 2008; 586: 5701-5715.

143 Price TJ, Cervero F, Gold MS, Hammond DL, Prescott SA. Chloride regulation in the pain pathway. Brain Res Rev 2009; 60: 149-170.

144 Castro-Lopes JM, Malcangio M, Pan BH, Bowery NG. Complex changes of GABAA and $\mathrm{GABAB}$ receptor binding in the spinal cord dorsal horn following peripheral inflammation or neurectomy. Brain Res 1995; 679: 289-297.

145 Hains BC, Saab CY, Waxman SG. Changes in electrophysiological properties and sodium channel Nav13 expression in thalamic neurons after spinal cord injury. Brain 2005; 128: 2359-2371.

146 Zhao P, Waxman SG, Hains BC. Sodium channel expression in the ventral posterolateral nucleus of the thalamus after peripheral nerve injury. Mol Pain 2006; 2: 27.

147 Todorovic SM, Jevtovic-Todorovic V. T-type voltage-gated calcium channels as targets for the development of novel pain therapies. Br J Pharmacol 2011; 163: 484-495.

148 Ralston HJ 3rd, Ohara PT, Meng XW, Wells J, Ralston DD. Transneuronal changes of the inhibitory circuitry in the macaque somatosensory thalamus following lesions of the dorsal column nuclei. J Comp Neurol 1996; 371: 325-335.

149 Jeanmonod D, Magnin M, Morel A. Thalamus and neurogenic pain: physiological anatomical and clinical data. Neuroreport 1993; 4: 475-478.

150 Weng HR, Lee JI, Lenz FA, Schwartz A, Vierck C, Rowland L et al. Functional plasticity in primate somatosensory thalamus following chronic lesion of the ventral lateral spinal cord. Neuroscience 2000; 101: 393-401. 